\title{
Exclusive Breastfeeding and Upper Respiratory Infection in Infants Aged 6-12 Months in Kampar District, Riau Province
}

\author{
Air Susu Ibu Eksklusif dan Infeksi Saluran Pernapasan Atas pada Bayi Usia \\ 6-12 Bulan di Kabupaten Kampar, Provinsi Riau
}

\author{
Musfardi Rustam*, Renti Mahkota**, Nasrin Kodim**
}

*Riau Province Health Officer, Riau, Indonesia, **Department of Epidemiology, Faculty of Public Health, Universitas Indonesia, Depok, Indonesia

\begin{abstract}
Upper respiratory infection (URI) is a major cause of morbidity and mortality in infants and toddlers in developing countries. The high infant morbidity and mortality rates in Indonesia are associated with the low exclusive breastfeeding rates. Breast milk is a natural drink for newborns in the first month of life and is beneficial not only for the infants, but also for the mothers. The aim of this study was to determine association ofexclusive breastfeeding practise and URI in infants aged 6-12 months. This study used a case-control design, and cluster random sampling was done. The study consisted of 162 cases and 162 control subjects aged 6-12 months. The study was conducted from December 2009 to June 2010 in Kampar District. Data analysis included univariate, bivariate, stratification, and multivariate with logistic regression. Results found that infants who were not exclusively breastfed were 1.69 times (95\% Cl: 1.02-2.80) more at risk of URI compared with those who were exclusively breastfed after controlling for the presence of a smoker at home and immunization.
\end{abstract}

Keywords: Exclusive breastfeeding, upper respiratory infection, infants aged 6 - 12 months

\begin{abstract}
Abstrak
Penyakit infeksi saluran pernapasan atas (ISPA) merupakan penyebab utama kesakitan dan kematian bayi dan balita di negara berkembang. Angka kesakitan dan kematian bayi yang tinggi di Indonesia berhubungan dengan kemampuan pemberian air susu ibu (ASI) secara eksklusif yang rendah. ASI yang merupakan minuman alami bayi baru lahir pada bulan pertama kehidupan yang bermanfaat tidak hanya untuk bayi, tetapi juga untuk ibu. Tujuan penelitian untuk mengetahui ASI eksklusif dan ISPA pada bayi usia 6 -12 bulan. Penelitian ini dilakukan dengan menggunakan desain kasus kontrol. Penarikan sampel menggunakan cluster random sampling. Subjek penelitian meliputi 162 kasus dan 162 kontrol bayi berusia 6 -12 bulan. Penelitian dilakukan selama Desember 2009 sampai Juni 2010 di Kabupaten Kampar. Analisis data meliputi analisis univariat, bivariat, stratifikasi, serta analisis multivariat dengan regresi logistik. Hasil penelitian menemukan bahwa bayi yang diberi ASI ekslusif berisiko 1,69 kali mengalami infeksi saluran pernapasan atas dibandingkan dengan bayi yang diberi ASI eksklusif setelah dikontrol variabel adanya perokok dalam rumah dan status imunisasi tidak lengkap.
\end{abstract}

Kata kunci: Air Susu lbu eksklusif, infeksi saluran pernapasan atas, bayi berusia 6 - 12 bulan

How to Cite: Rustam M, Mahkota R, Kodim N. Exclusive breastfeeding and decrease in upper respiratory infection incidence in infants aged 6-12 months in Kampar District, Riau Province. Kesmas: National Public Health Journal. 2019; 13 (3): 117-123. (doi:10.21109/kesmas.v13i3.1892)
Correspondence: Musfardi Rustam, Riau Province Health Officer, Cut Nyak Dien Street III, Pekan Baru, Riau, Indonesia, Phone: -, E-mail: musfardirustam@gmail.com

Received: November $20^{\text {th }} 2017$

Revised: March 23th 2018

Accepted: April $10^{\text {th }} 2018$ 


\section{Introduction}

Upper respiratory infection (URI) is an acute disease that attacks one and/or more of the respiratory tract from the nose to the alveoli including the adnexal tissues such as sinuses, middle ear, and pleural cavities. ${ }^{1}$ URI is a major cause of morbidity and mortality in infants and toddlers in developing countries with a global mortality rate of $19 \%$ and $26 \%$, respectively. ${ }^{2}$

URI is still an important public health problem in Indonesia. According to the 2007 National Basic Health Research, ${ }^{3}$ the prevalence of URI among toddlers in Indonesia is $11 \%$ based on subjective maternal perceptions of URI two weeks before the survey without verification from a paramedic. In addition, the proportion of highly febrile infants was in the $6-11$ months age group at $39.9 \%$ with URI symptom at $12.2 \%$. The national prevalence of the URI incidence based on the diagnosis of the health officers and respondents' complaints is $25.50 \%$. The prevalence of URI in Riau Province is under the national prevalence at $22.87 \% .^{4}$

The high morbidity and mortality rates in Indonesia are related to mothers' inability to breastfeed. ${ }^{5}$ Breast milk is a natural drink for newborns in the first month of life and is beneficial not only for infants, but also for mothers, families, and countries. ${ }^{6}$ The World Health Organization (WHO) and United Nations International Children's Emergency Fund (UNICEF) recommend exclusive breastfeeding for infants to be implemented from birth to six months of life without additional food and drinks, except medicines and vitamins.

In several studies, there are many risk factors of URI incidence in infants and toddlers, including malnutrition, low birth weight, insufficient breastfeeding provision, high occupancy house, incomplete immunization, sex, vitamin A deficiency, iron deficiency, vitamin D or calcium deficiency, infant's age, smoker at home, healthcare services, low socioeconomic status, and cigarette smoke. ${ }^{7,8}$ The high rate of URI prevalence and the low coverage of exclusive breastfeeding are problems that need attention. Therefore, this study aims to determine exclusive breastfeeding and URI in infants aged 6-12 months in Kampar District.

\section{Method}

This study was carried out quantitatively using a casecontrol design. The Lemeshow formula we used to calculate sample size for hypothesis test for two population proportion. ${ }^{9}$ Data were collected through a structured interview using a questionnaire and observation. The study was conducted from December 2009 to June 2010 including early surveying, early data collecting, proposal writing, primary data collecting, and study result writing.

Sampling was done to a total of 6,088 infants aged 6-
12 months carried by their mothers to 27 selected primary health cares. Of which, 3,700 infants from 15 selected primary health care were eligible for the study population. The sampling was conducted within 1 year, in which there were 1,325 infants aged 6-12 months who reportedly suffered from URI and 2,375 infants who did not. The sampling method was based on the assumption that the characteristics of the study subjects in all the primary health care were the same. In cluster sampling, the sampling unit was a primary health care that would take 162 case and 162 control samples. The case and control subjects were selected by random sampling at primary health care. The samples were obtained from 15 out of the 27 selected primary health care in Kampar District that had the highest URI incidence.

This study used primary data including child characteristics factor (measles and diphtheria and pertussis (DPT) immunization records, nutritional status, sex, age, and birth weight), maternal sociodemographic factor (education, knowledge, and occupation), and environmental factors (the presence of smokers and the presence of exposure to cooking fire at home). The case group is composed of infants aged 6-12 months who visited the selected primary health care for treatment and were diagnosed with URI. The control group consisted of infants not diagnosed with URI by a doctor or paramedic. All the samples who met the criteria were followed up through an interview using a questionnaire and were observed. Data collection was conducted by a structured questionnaire to mothers whose infants were selected to be case and control samples. In addition, measurement and observation were also done to obtain the infants' body weight, DPT and measles immunization records, and the presence of cigarette smoke at home. Moreover, data were validated by the truth of information of the study subjects such as the birth date of infant and by the health card (Kartu Menuju Sehat/KMS) owned.

The collected data processing was carried out using manual method and computer including data editing, coding, entry and processing, and cleaning. Stata 15 application was used to analyze the data, univariate analysis to determine the distribution of each variable, bivariate analysis to select variables and multivariate analysis, using multiple logistic regression to determine relationship between exclusive breastfeeding and URI.

\section{Results}

Univariate analysis was applied to 324 subjects, including 162 cases and 162 controls, to describe the characteristics of each study variable with the frequency distribution of every group.

Results have shown that the proportion of mothers who did not exclusively breastfeed their infants was higher at $66.05 \%$. The proportion of non-exclusively breast- 
Table 1. Distribution of Exclusive Breastfeeding Practice and Child Characteristic Factor

\begin{tabular}{|c|c|c|c|c|c|c|c|}
\hline \multirow{2}{*}{ Variable } & \multirow{2}{*}{ Category } & \multicolumn{2}{|c|}{ URI } & \multicolumn{2}{|c|}{ Non URI } & \multicolumn{2}{|c|}{ Total } \\
\hline & & $\mathbf{n}$ & $\%$ & $\mathbf{n}$ & $\%$ & $\mathbf{n}$ & $\%$ \\
\hline \multicolumn{8}{|c|}{ Exclusive breastfeeding practice } \\
\hline \multirow{2}{*}{ Exclusive breastfeeding } & Yes & 42 & 25.93 & 68 & 41.98 & 110 & 33.95 \\
\hline & No & 120 & 74.07 & 94 & 58.02 & 214 & 66.05 \\
\hline \multicolumn{8}{|l|}{ Child characteristic factor } \\
\hline \multirow[t]{7}{*}{ Age of infants (months) } & 6 & 32 & 19.75 & 16 & 9.88 & 48 & 14.81 \\
\hline & 7 & 24 & 14.81 & 26 & 16.05 & 50 & 15.43 \\
\hline & 8 & 22 & 13.58 & 28 & 17.28 & 50 & 15.43 \\
\hline & 9 & 18 & 11.11 & 23 & 14.20 & 41 & 12.65 \\
\hline & 10 & 21 & 12.96 & 31 & 19.14 & 52 & 16.05 \\
\hline & 11 & 20 & 12.35 & 21 & 12.96 & 41 & 12.65 \\
\hline & 12 & 25 & 15.43 & 17 & 10.49 & 42 & 12.96 \\
\hline \multirow[t]{2}{*}{ Immunization status } & Complete & 44 & 27.16 & 15 & 9.26 & 59 & 18.21 \\
\hline & Incomplete & 118 & 72.84 & 147 & 90.74 & 265 & 81.79 \\
\hline \multirow[t]{3}{*}{ Infant's nutritional status } & Normal & 105 & 64.81 & 98 & 60.49 & 203 & 62.65 \\
\hline & Fat & 34 & 20.99 & 21 & 12.96 & 55 & 16,98 \\
\hline & Thin & 23 & 14.20 & 43 & 26.54 & 23 & 20.37 \\
\hline \multirow[t]{2}{*}{ Sex } & Male & 96 & 59.2 & 82 & 50.62 & 178 & 54.94 \\
\hline & Female & 66 & 6 & 80 & 49.38 & 146 & 45.06 \\
\hline \multirow[t]{2}{*}{ Birth weight } & Low & 5 & 3.09 & 4 & 2.47 & 9 & 2.78 \\
\hline & Normal weight & 157 & 96.9 & 158 & 97.53 & 315 & 97.22 \\
\hline
\end{tabular}

Note:

URI = Upper Respiratory Infection

Table 2. Distribution of Sociodemographic and Environmental Factor of Respondents

\begin{tabular}{|c|c|c|c|c|c|c|c|}
\hline \multirow{2}{*}{ Variable } & \multirow{2}{*}{ Category } & \multicolumn{2}{|c|}{ URI } & \multicolumn{2}{|c|}{ Non URI } & \multicolumn{2}{|c|}{ Total } \\
\hline & & $\mathbf{n}$ & $\%$ & $\mathbf{n}$ & $\%$ & $\mathbf{n}$ & $\%$ \\
\hline \multicolumn{8}{|l|}{ Sociodemographic factor } \\
\hline \multirow[t]{2}{*}{ Maternal education } & $\leq$ Junior high school & 82 & 50.62 & 73 & 45.06 & 155 & 47.84 \\
\hline & $\geq$ Senior high school & 80 & 49.38 & 89 & 54.94 & 169 & 52.16 \\
\hline \multirow[t]{2}{*}{ Maternal knowledge } & Adequate & 80 & 49.38 & 85 & 52.47 & 165 & 50.93 \\
\hline & Inadequate & 82 & 50.62 & 77 & 47.53 & 159 & 49.07 \\
\hline \multirow[t]{2}{*}{ Maternal occupation } & Employed & 34 & 20.99 & 31 & 19.14 & 65 & 20.06 \\
\hline & Unemployed & 128 & 79.01 & 131 & 80.86 & 259 & 79.94 \\
\hline \multicolumn{8}{|l|}{ Environmental factor } \\
\hline \multirow[t]{2}{*}{ Smoker at home } & No & 21 & 12.96 & 51 & 31.48 & 72 & 22.22 \\
\hline & Yes & 141 & 87.04 & 111 & 68.52 & 252 & 77.78 \\
\hline The presence of exposure & No & 135 & 83.33 & 131 & 80.86 & 266 & 82.10 \\
\hline to cooking fire at home & Yes & 27 & 16.67 & 31 & 19.14 & 58 & 17.90 \\
\hline
\end{tabular}

Note:

URI = Upper Respiratory Infection

fed infants who suffered from URI (case) was higher at $74.07 \%$ than those with no URI at $58.02 \%$. The proportion of infants exclusively breastfed was higher in the control group at $41.98 \%$ than in the case group at $25.93 \%$.

The majority of the group of infants was 10 months old with 52 samples $(16.05 \%)$, and the smallest proportion was 11 months old with 41 samples $(12.65 \%)$. There were more male samples at $178(54.94 \%)$ than female subjects at $146(45.06 \%$; Table 1$)$. In the birth weight variable, most of the infants were non-low birth weight with a total of 315 samples $(97.22 \%)$, whereas infants with low birth weight were only $9(2.78 \%)$.
In the maternal education level variable, the proportion of high-educated respondents was higher at $52.16 \%$ than the low-educated ones at $47.84 \%$ (Table 2). In the knowledge variable, respondents had adequate knowledge of URI at $50.93 \%$. In the occupation variable, the proportion of unemployed respondents was higher $(79.94 \%)$ than the employed $(20.06 \%)$.

The smokers at home took the highest proportion at $77.78 \%$, while the lowest was outside the house at $22.22 \%$ (Table 2). Meanwhile, the absence of exposure to cooking fire at home showed a proportion of $82.10 \%$, while the presence of exposure to cooking fire at home was the lowest at $17.90 \%$. 
Table 3. Bivariate Analysis on Exclusive Breastfeeding and Upper Respiratory Infection

\begin{tabular}{|c|c|c|c|c|c|c|c|c|c|}
\hline \multirow{2}{*}{ Variable } & \multirow{2}{*}{ Category } & \multicolumn{2}{|c|}{ URI } & \multicolumn{2}{|c|}{ Non URI } & \multirow{2}{*}{$\mathrm{X}^{2}$} & \multirow{2}{*}{ p-Value } & \multirow{2}{*}{ Crude OR } & \multirow{2}{*}{$95 \% \mathbf{C I}$} \\
\hline & & $\mathbf{n}$ & $\%$ & $\mathbf{n}$ & $\%$ & & & & \\
\hline Exclusive breastfeeding & $\begin{array}{l}\text { Yes } \\
\text { No }\end{array}$ & $\begin{array}{r}42 \\
120\end{array}$ & $\begin{array}{l}25.93 \\
74.07\end{array}$ & $\begin{array}{l}68 \\
94\end{array}$ & $\begin{array}{l}41.98 \\
58.02\end{array}$ & 9.30 & 0.001 & 2.06 & $1.26-3.40$ \\
\hline
\end{tabular}

Notes:

$\mathrm{URI}=$ Upper Respiratory Infection, OR = Odds Ratio, $\mathrm{CI}=$ Confidence Interval

Table 4. Bivariate Analysis on Risk Factors of Upper Respiratory Infection

\begin{tabular}{|c|c|c|c|c|c|c|c|c|c|}
\hline \multirow{2}{*}{ Variable } & \multirow{2}{*}{ Category } & \multicolumn{2}{|c|}{ URI } & \multicolumn{2}{|c|}{ Non URI } & \multirow{2}{*}{$\mathrm{X}^{2}$} & \multirow{2}{*}{ p-Value } & \multirow{2}{*}{ Crude OR } & \multirow{2}{*}{ 95\% CI } \\
\hline & & $\mathbf{n}$ & $\%$ & $\mathbf{n}$ & $\%$ & & & & \\
\hline \multirow[t]{3}{*}{ Infant's nutritional status } & Normal & 105 & 64.81 & 98 & 60.49 & - & - & 1.00 & Ref \\
\hline & Fat & 34 & 20.99 & 21 & 12.96 & 1.77 & 0.18 & 1.51 & $0.81-2.78$ \\
\hline & Thin & 66 & 14.20 & 43 & 26.54 & 5.67 & 0.01 & 0.49 & $0.27-0.89$ \\
\hline \multirow[t]{2}{*}{ Birth weight } & Normal birth weight & 157 & 96.91 & 158 & 97.53 & 0.11 & 0.73 & 1.25 & $0.26-6.45$ \\
\hline & Low birth weight & 5 & 3.09 & 4 & 2.47 & & & & \\
\hline \multirow[t]{2}{*}{ Sex } & Male & 96 & 59.26 & 82 & 50.62 & 2.44 & 0.11 & 1.41 & $0.89-2.25$ \\
\hline & Female & 66 & 40.74 & 80 & 49.38 & & & & \\
\hline \multirow[t]{2}{*}{ Immunization status } & Complete & 118 & 72.84 & 147 & 90.74 & 17.4 & 0.001 & 3.65 & $1.87-7.40$ \\
\hline & Incomplete & 44 & 27.16 & 15 & 9.26 & & & & \\
\hline \multirow[t]{7}{*}{ Age of infant (months) } & 6 & 32 & 19.75 & 16 & 9.88 & - & - & 1.00 & Ref \\
\hline & 7 & 24 & 14.81 & 26 & 16.05 & 3.45 & 0.06 & 0.46 & $0.19-1.06$ \\
\hline & 8 & 22 & 13.58 & 28 & 17.28 & 5.03 & 0.02 & 0.39 & $0.16-0.91$ \\
\hline & 9 & 18 & 11.11 & 23 & 14.20 & 4.60 & 0.03 & 0.39 & $0.16-0.95$ \\
\hline & 10 & 21 & 12.96 & 31 & 19.14 & 6.85 & 0.00 & 0.33 & $0.14-0.79$ \\
\hline & 11 & 20 & 12.35 & 21 & 12.96 & 2.88 & 0.08 & 0.47 & $0.19-1.14$ \\
\hline & 12 & 25 & 15.43 & 17 & 10.49 & 0.49 & 0.48 & 0.73 & $0.30-1.75$ \\
\hline \multirow[t]{2}{*}{ Knowledge } & Adequate & 80 & 49.38 & 85 & 52.47 & - & - & 1.00 & Ref \\
\hline & Inadequate & 82 & 50.62 & 77 & 47.53 & 0.30 & 0.57 & 1.13 & $0.7-1.79$ \\
\hline \multirow[t]{2}{*}{ Education } & High & 49.38 & 89 & 54.94 & - & - & 1.00 & Ref & \\
\hline & Low & 82 & 50.62 & 73 & 45.06 & 1.00 & 0.31 & 1.24 & $0.78-1.98$ \\
\hline \multirow[t]{2}{*}{ Occupation } & Unemployed & 128 & 79.01 & 131 & 80.86 & - & - & 1.00 & Ref \\
\hline & Employed & 34 & 20.99 & 31 & 19.14 & 0.17 & 0.67 & 1.12 & $0.62-2.00$ \\
\hline \multirow[t]{2}{*}{ Smoker at home } & No & 21 & 12.96 & 51 & 31.48 & - & - & 1.00 & Ref \\
\hline & Yes & 141 & 87.04 & 111 & 68.52 & 16.07 & 0.00 & 3.08 & $1.69-5.71$ \\
\hline \multirow{2}{*}{$\begin{array}{l}\text { The presence of exposure } \\
\text { to cooking fire }\end{array}$} & No & 135 & 83.33 & 131 & 80.86 & - & - & 1.00 & Ref \\
\hline & Yes & 27 & 16.67 & 31 & 19.14 & 0.34 & 0.56 & 0.84 & $0.45-1.55$ \\
\hline
\end{tabular}

Notes:

$\mathrm{URI}=$ Upper Respiratory Infection, OR = Odds Ratio, CI = Confidence Interval, Ref = Reference

The results on bivariate analysis indicated that infants who were not exclusively breastfed were 2.1 times (95\% confidence interval [CI]: 1.26-3.40) more likely to suffer from URI compared with those who were exclusively breastfed, which was statistically significant with p-value $=0.001$ (Table 3$)$.

The stages of multivariate analysis are candidate variable selection (Table 3 and Table 4 ), basic model arrangement, interaction test, confounding test, and final model arrangement. After the multivariate analysis was applied to each variable, a parsimonious final model was obtained, which showed the real relation between the selected independent variable and the dependent variable. The obtained final model of multivariate is found in Table 5.

The results of the study revealed that infants who were not exclusively breastfed had 1.69 times (95\% CI:
1.02-2.80) likelihood of suffering from URI compared with infants who were exclusively breastfed, with a statistically significant $\mathrm{p}$-value $=0.03$ after controlled by the presence of a smoker at home and incomplete immunization status (Table 5). The results proved the study's hypothesis that states that exclusive breastfeeding associated with URI in infants aged 6-12 months compared with infants who were not exclusively breastfed in Kampar District. Immunization and the presence of a smoker at home were confounding variables and substantially significantly related to exclusive breastfeeding. The equation of the final model obtained in this study is as Equation 1.

\section{Discussion}

Exclusive breastfeeding is an important part of nutrition to decrease the incidence of URI and to promote the 
Table 5. The Final Model of Multivariate Analysis on Exclusive Breastfeeding and Upper Respiratory Infection

\begin{tabular}{lccrrr}
\hline Variable & B & SE & p-Value & OR & 95\% CI \\
\hline Exclusive breastfeeding practice & 0.52 & 0.43 & 0.03 & 1.69 & $1.02-2.80$ \\
The presence of smoker & 1.01 & 0.83 & 0.001 & 2.75 & $1.51-4.99$ \\
Incomplete immunization & 1.30 & 1.23 & 0.001 & 3.68 & $1.91-7.09$ \\
Constant & -1.36 & 0.30 & 0.001 & - & - \\
\hline
\end{tabular}

Notes:

$\mathrm{OR}=$ Odds Ratio, $\mathrm{CI}=$ Confidence Interval, $\mathrm{SE}=$ Standard Error

Equation 1.

Logit $\mathrm{P}(\mathrm{URI}$ in infants $)=\beta \mathrm{o}+\beta$ (ASI) $+\beta$ (the presence of smoker $)+\beta$ (Immunization)

Logit $\mathrm{P}(\mathrm{URI}$ in infants $)=-1.36+0.52$ (Breastfeeding $)+1.01$ (The presence of smoker $)+1.30$ (Immunization)

health, growth, and development of infants in the first year of life. ${ }^{10,11}$ From the final model results of multivariate analysis, infants who were not exclusively breastfed had an odds ratio (OR) of 1.69 times (95\% CI: 1.022.80) to suffer from URI compared with infants who were exclusively breastfed, with a statistically significant $\mathrm{p}$-value $=0.03$ after controlling for the presence of a smoker at home and incomplete immunization status. Infants who were not exclusively breastfed were mostly found in the case group (URI) compared with the control group (non-URI). This result is the same as the previous studies that emphasized the importance of promoting exclusive breastfeeding to infants until the age 6 months. ${ }^{11}$, 12,13

The results of this study show that an improvement program for breastfeeding practice is needed, with priorities focused on exclusive breastfeeding and URI disease handling because of its huge impact toward infants' health. Breast milk has elements that meet all the infant's needs of nutrients during a period of about six months unless the mother suffers from a heavy undernourished condition and the breast milk composition changes along with the infant's needs. Antibodies and macrophage cells in breast milk and colostrum provide protection against certain kinds of infections; therefore, infants who receive exclusive breastfeeding are rarely affected by respiratory infectious diseases and diarrhea. International health organizations recommend exclusive breastfeeding for 6 months as a universal standard of optimal infant feeding practices. $^{2}$

A study by Tromp et al, ${ }^{14}$ found that infants who receive exclusive breastfeeding automatically receive an anti-infection immunity. Exclusive breastfeeding also gives passive protection against pathogens entering the infant's body. Breast milk contains various antimicrobial substances, anti-inflammatory components, and immune development factors. It is the best natural food mothers can provide to their children, as its composition fits with the infants' growth and development and also helps protect the infants from any infectious diseases. ${ }^{15}$ A study by Lars, ${ }^{12}$ showed that exclusive breastfeeding provides protection through SigA antibody that can protect infants from Haemophilus influenza microbes in the mouth and nose and decrease the risk of respiratory tract infection.

The results of this study proved that exclusive breastfeeding was related to URI in infants aged 6-12 months in Kampar District. URI handling was carried out not only through treatment (curative), but also through enhancement of promotive and preventive efforts. In decreasing the rate of infant morbidity due to URI, risk factor countermeasures need to be implemented through both cross-program and cross-sectoral cooperations. The cooperation can be conducted through programs focused on immunization, public nutrition development, toddler health development, settlement environmental sanitation program, health promotion, and exclusive breastfeeding provision program improvement. Cross-sectoral cooperation involves local police, information office, education office, subdistrict office, and public figures.

The development of URI disease countermeasures program can be performed through advocacy and socialization, invention and governance, community empowerment, partnership, logistic management improvement, program management, study and development program, and risk factor prevention and countermeasures.

Advocacy and socialization are the most important activities in URI countermeasures efforts to get political commitment and awareness from all decision-makers and cooperation from all people. A medium for URI countermeasures coordination needs to be established in Kampar District that is cross-program, cross-sectoral, and involves non-government element and related professional organizations.

Improvement of the quality of URI countermeasures services can be done by enhancing human resource's capability through training, drug availability, needed medical equipment, and routine recording and reporting 
validity. Implementation of supervision is intensively done by the responsible person of the program by running an early monitoring system and evaluation program. Development of community participation is really needed in decreasing the incidence of URI through cooperations with the Family Welfare Movement cadres and health cadres to guide and motivate breastfeeding mothers in providing the 6-month exclusive breastfeeding.

Management of URI countermeasures program starts from planning, implementing, budgeting, monitoring, and evaluating both at central, province, district/city, and health services unit levels.

Incomplete immunization records, especially for measles and DPT had 3.68 times (95\% CI= 1.51-4.99) risk of URI incidence among infants aged 6-12 months, which is higher than valid provision of measles and DPT immunization, with a statistically significant $\mathrm{p}$-value $=$ 0.001 .16 The valid provision or timing of infant immunization must be conducted in accordance with the correct time interval.

A study by Naim, ${ }^{17}$ stated that measles immunization has 2.37 times $(95 \% \mathrm{CI}=1.49-3.77)$ risk of pneumonia incidence in infants aged 4-24 months that is higher than infants who do not receive measles immunization, which is statistically significant with a p-value $=0.03$.

The immunization status received by infants will affect the incidence of infection because the provision of immunization aims to provide immunity. ${ }^{18}$ The same perspective is stated by WHO, 16 saying that immunization is one of most effective and efficient ways to prevent an infectious disease. The presence of a smoker at home variable had 2.75 times (95\% CI= 1.51-4.99) risk of URI incidence in infants aged 6-12 months that was higher compared with the absence of a smoker at home, which was statistically significant with a $p$-value $=0.001$. The result of this study was similar to the study by Purwana, ${ }^{19}$ which mentioned that the presence of a smoker at home (family member) is the risk factor of URI incidence in infants.

The presence of a smoker at home was a variable affecting the incidence of URI. Cigarette causes air pollution at home that can hinder the mechanism of respiratory tract defense, which results in URI diseases among infants. However, this study did not conduct a deeper assessment, such as the number of cigarettes smoked per day, type of cigarettes, and the number of smokers at home. A prospective cohort study may determine the exposure properly because of accurate data validity problem; hence, it drops bias.

A study by Purwana, ${ }^{19}$ showed that cigarette smoke inhaled by infants can damage airway resistance, such as the mucociliary clearance function. Cigarette consumption by fathers evidently increases the risk for toddlers to get affected by a respiratory disorder. A longitudinal study by Mascola et al, 20 found that smoker mothers affect their infants through cotinine, which enters the breast milk and can be detected in the infant's urine. In smoker mothers, urinary cotinine is found to be 10 times higher in breastfed infants. Toddlers also have higher urinary cotinine level at smoking homes. Cotinine is a chemical produced when the body damages nicotine from the inhaled smoke.

A retrospective cohort design study by Nafstad et $a l, 21$ in Oslo, Norway, determined the relation between the provision of breast milk and the presence of smokers with the incidence of pneumonia. Infants who received breast milk at the age of 0-6 months from smoker mothers have an increased risk of pneumonia $(\mathrm{OR}=1.7 ; 95 \%$ $\mathrm{CI}=1.2-2.4$ ), whereas infants who received breast milk at the age of 6-12 months from the smoker mothers did not increase the risk of pneumonia significantly $(\mathrm{OR}=$ $1.1 ; 95 \% \mathrm{CI}=0.7-1.6)$. Health education programs are targeted to reduce the prevalence of cigarette smoking individuals, promote laws regulating or prohibiting smoking in public places, increase taxes on cigarettes, and file successful court cases that forced tobacco companies to pay some of the health cost incurred from cigarette-related illnesses. ${ }^{10} \mathrm{~A}$ study by Tromp, ${ }^{14}$ indicated the relation between the duration and dose of breastfeeding and upper respiratory tract infection, but it is not significant.

Anti-smoking campaign programs, which include setting up non-smoking area, need to be applied in the homes, community, and country. Health education to reduce smoke exposure at the house environment and communication for non-smoking public areas and households should be made. ${ }^{22}$ The no-smoking counseling activity in the forms of communication, information, and education at home or at infant's room need to be encouraged continuously through a clean and healthy lifestyle. ${ }^{14}$

\section{Conclusion}

Exclusive breastfeeding was associated with URI in infants aged 6-12 months in Kampar District. Infants who are not exclusively breastfed have 1.69 times risk of suffering from URI compared with infants who are exclusively breastfed after controlling for the presence of a smoker at home and incomplete immunization.

\section{Recommendation}

The cooperation among immunization programs; smoking cessation campaign; 6-month exclusive breastfeeding practice improvement; URI countermeasures program development by advocacy, partnership, research, management improvement, prevention, and risk factor countermeasures; toddler immunization coverage improvement by counseling to mothers about the importance of immunization in giving immunity against dis- 
eases (immune system); and anti-smoking campaign program that includes setting up a no smoking area by the family, country, and community are recommended. The no-smoking counseling activity in the forms of communication, information, and education at home or at infant's room need to be encouraged continuously through a clean and healthy lifestyle.

Other researchers may carry out a follow-up study by using better designs and methods, such as a prospective cohort design, to obtain the relation between exclusive breastfeeding and URI at the same place or elsewhere.

\section{References}

1. Departemen Kesehatan RI. Pedoman program pemberantasan penyakit infeksi saluran pernafasan akut. Jakarta: Departemen Kesehatan RI; 2007.

2. World Health Organization. The World Health Report 2005, Attending to 136 million birth, every years. Geneva: World Health Organization; 2005.

3. Badan Penelitian dan Pengembangan Kesehatan Departemen Kesehatan RI. Riset kesehatan dasar 2007. Jakarta: Badan Penelitian dan Pengembangan Kesehatan Departemen Kesehatan RI; 2008.

4. Dinas Kesehatan Provinsi Riau. Profil kesehatan Propinsi Riau 2008. Pekanbaru: Dinas Kesehatan Provinsi Riau; 2009.

5. Nelson. Ilmu kesehatan anak. Jakarta: EGC; 2004.

6. Roesli U. Mengenal ASI ekslusif. Jakarta: Cetakan I Trubus Agriwidya; 2000.

7. Martin MA, Garcia G, Kaplan HS, Gurven MD. Social Science \& medicine conflict or congruence? Maternal and infant-centric factors associated with shorter exclusive breastfeeding durations among the Tsimane. Social Science and Medicine [Internet]. 2016;170:9-17. Available from: http://dx.doi.org/10.1016/j.socscimed.2016.10.003

8. Jamison DT, Breman JG, Measham AR, Alleyne G, Cleason M, Evans DB, et al. Disease control priorities in developing countries. New York: Oxford University Press; 2006.

9. Hosmer DW, Lemeshow S. Applied regression logistic. USA: A Wiley Interscience Publication; 2000.

10. Nelson KE, Williams CM, Graham NMH. Infectious disease epidemiology. 3d ed. Burlington: Jones and bartlett Learning; 2014. 587 p.
11. Lindsay A, Le Q, Greaney M. Infant feeding beliefs, attitudes, knowledge and practices of chinese immigrant mothers: an integrative review of the literature. International Journal of Environmental Research and Public Health [Internet]. 2017;15(2):21. Available from: http://www.mdpi.com/1660-4601/15/1/21

12. Duijts L, Jaddoe VW V, Hofman A, Moll HA. Prolonged and exclusive breastfeeding reduces the risk of infectious diseases in infancy. Pediatrics [Internet]. 2010;126(1):e18-25. Available from: http://pediatrics.aappublications.org/cgi/doi/10.1542/peds.2008-3256

13. Gençer MZ, Alıcıo lu F, Arıca S, A ırman E, E ici MT, Arıca V. The effects of breastfeeding duration on the frequency of upper respiratory tract infection in the advancing years of life. International Annals of Medicine. 2017;1(7):1-5.

14. Tromp I, Jong JK, Raat H, Jaddoe V, Franco O, Hofman A, et al. Breastfeeding and the risk of respiratory tract infections after infancy: the generation R study. Plos One. 2017; 0172763: 1-12.

15. Lawrence R. Breastfeeding: a guide for the medical profession. 6th ed. St Louis: Mosby Inc; 2005.

16. World Health Organization. Immunization coverage cluster survey-reference manual. Geneva, Switzerland: World Health Organization; 2005.

17. Naim. Hubungan pemberian ASI Esklusif terhadap kejadian pneumonia pada anak umur 4-24 bulan di Kabupaten Indramayu [Tesis]. Depok: Fakultas Kesehatan Masyarakat Universitas Indonesia; 2001.

18. Lanata CF, Rudan I, Boschi-pinto C, Tomaskovic L, Cherian T, Weber $\mathrm{M}$, et al. Methodological and quality issues in epidemiological studies of acute lower respiratory infections in children in developing countries. International Journal of Epidemiology. 2017;33(6):1362-72.

19. Purwana R. Partikulat rumah sebagai faktor resiko gangguan pernafasan anak balita [Desertasi]. Depok: Universitas Indonesia; 1999.

20. Mascola MA, Vunakis H Van, Tager IB, Speizer FE, Hanrahan JP. Exposure of young infants to environmental tobacco smoke : breastfeeding among smoking mothers. American Journal of Public Health. 1997; 88 (6): 893-6.

21. Nafstad P, Jaakkola JJK, Hagen JA, Botten G, Kongerud J. Breastfeeding, maternal smoking, and lower respiratory tract infections. European Respiratory Journal. 1996; 9(12):1623-9.

22. Risica PM, McCausland K. Infant feeding decisions and behaviours among low-income smoke-exposed women: timing and change during pregnancy. Public Health Nutrition. 2017;20(15):2796-805. 